\title{
Inter-annual climate variability and zooplankton: applying teleconnection indices to two deep subalpine lakes in Italy
}

\author{
Marina MANCA, ${ }^{1 *}$ Michela ROGORA, ${ }^{1}$ Nico SALMASO ${ }^{2}$ \\ ${ }^{1}$ CNR - Institute of Ecosystem Study, Largo Tonolli 50, 28922 Verbania Pallanza; ${ }^{2}$ Sustainable Agro-ecosystems and Bioresources \\ Department, IASMA Research and Innovation Centre, Istituto Agrario di S. Michele all'Adige, Fondazione E. Mach, via E. Mach 1, \\ 38010 S. Michele all'Adige, Trento, Italy \\ *Corresponding author: m.manca@ise.cnr.it
}

\begin{abstract}
Investigating relation between meteo-climatic indices and between-year variation in Daphnia population density and phenology is crucial for e.g. predicting impact of climate change on lake ecosystem structure and functioning. We tested whether and how two teleconnection indices calculated for the winter period, namely the East Atlantic pattern $\left(E A_{D J F}\right)$ and the Eastern Mediterranean Pattern $\left(E M P_{D J F}\right)$ were correlated with Daphnia population growth in two Italian subalpine lakes, Garda and Maggiore. We investigated between-lake temporal coherence in: i) water temperature within the water layer in which Daphnia is distributed; ii) timing of Daphnia initial and spring maximum population density peak and iii) the level of Daphnia spring maximum population density peak over an eleven-year period (1998-2008) of unchanged predation pressure by fish and invertebrates, and of common oligotrophy. Between-lake temporal coherence was high for an earlier start, and earlier, and lower, Daphnia population spring density peak after milder winters. Peak density level was coherently, positively correlated with soluble reactive phosphorus (SRP) concentration. We hypothesized that Daphnia peak densities were related to atmospheric modes of variability in winter and to the degree of late winter mixing promoting replenishment of algal nutrients into upper water layers and phytoplankton growth, enhancing food availability and Daphnia fecundity, promoting and Daphnia peak.
\end{abstract}

Key words: Climate change, population phenology, Daphnia fecundity, SRP, phytoplankton.

Received: May 2014. Accepted: August 2014.

\section{INTRODUCTION}

Climate has increasingly been regarded as a major driver of changes in population phenology, directly and indirectly influencing between-year variability of seasonal cycles in terrestrial, marine and freshwater organisms (Winder and Schindler, 2004; Visser and Both 2005; Menzel et al., 2006; Richardson, 2006; Vadadi-Fülöp and Hufnagel, 2014).

The growing interest is also consequent to the awareness that we are facing a dramatic increase in ambient temperatures. The average increase in the observed annual mean temperature across Europe for the last century was $0.8^{\circ} \mathrm{C}$ (Dokulil et al., 2010). Temperature increase for the year 2035 is estimated as $2.0-3.5^{\circ} \mathrm{C}$, depending on the scenario and whether or not the damping by aerosols is considered (Kromp-Kolb, 2001). Temporal (between seasons) and spatial (between regions) variability of precipitations are also estimated to increase, with Northern Europe experiencing an increase in annual precipitations between 10$40 \%$ and increased risk of droughts in central and southern Europe. Ambient temperature changes and range of seasonal variations have been found to directly and indirectly influence timing and rates at which plants and heterotherms grow and reproduce along the season (Walther et al., 2002). By taxa- and population-specific responses, changes in ambient temperature also promote temporary changes in biotic interactions and predator-prey uncoupling, which ultimately result in changes in diversity and functioning of ecosystems (Moss et al., 2009; Shurin et al., 2010). The search for common responses at local, regional and global scales to changes in temperature has also resulted in increasing attention for possible common meteo-climatic drivers, causing temporal coherence observed at local level. Such effort was particularly important for lakes, regarded as sentinels and integrators of climate change (Adrian et al., 2009), acting as filters able to integrate and amplify the local climate (Blenckner, 2005; George, 2010).

An important role in this respect has been played by studies on crustacean zooplankton, because of their key, intermediate role, linking fast-reacting and fast-growing phytoplankton to upper levels of the food web exhibiting a delayed response to changes in climate. Pioneer studies, inspired by evidence from sea plankton (Taylor et al., 1992) and awareness that plankton succession in temperate lakes was strongly influenced by year-to-year variations in the weather (Reynolds, 1987), demonstrated that between-year variations in zooplankton biomass were closely correlated with meteo-climatic indices (namely, the latitude of the north wall of the Gulf Stream; George and Taylor, 1995). Successive research on meteoclimatic drivers of change in zooplankton have been mainly addressed to indices devel- 
oped for North America and Central Europe, particularly the North Atlantic Oscillation (NAO) index, calculated for the winter period (Hurrell et al., 2003). Comparison of response patterns to the winter (December-February) $\mathrm{NAO}_{\mathrm{DJF}}$ index, however, resulted in weak or inconsistent results when applied to lakes in the southern side of the Alps (Salmaso, 2005; Manca and DeMott, 2009; Dokulil et al., 2010). The Alps are indeed a barrier to the mass movement of air and cause the sharp climatic division between Atlantic, Continental and Mediterranean influences. Because of this barrier, lakes located in the southern flank of the Alps are likely somewhat shaded against influences of climatic indices to which lakes in Northern and Central Europe respond. In an attempt to find reliable drivers able to explain changes in phytoplankton taxa composition and nutrient dynamics of Lake Garda, Salmaso (2012) applied two other-than-NAO ${ }_{D J F}$ winter teleconnection indices of climate change, the Eastern Mediterranean Pattern $\left(\mathrm{EMP}_{\mathrm{DJF}}\right)$ and the East Atlantic $\left(\mathrm{EA}_{\mathrm{DJF}}\right)$ pattern for the winter (DecemberFebruary) period.

In the present paper, we tested $\mathrm{NAO}_{\mathrm{DJF}}, \mathrm{EMP}_{\mathrm{DJF}}$ and $\mathrm{EA}_{\mathrm{DJF}}$ teleconnection indices to investigate temporal coherence in seasonal dynamics of a key cladoceran zooplankter, Daphnia, in lakes of the subalpine region. We investigated the two large, deep lakes which are representative of the westernmost and easternmost part of the subalpine region, lakes Maggiore and Garda. At present, both are quite comparable for trophic status, i.e. they are characterised by oligotrophic (Lake Maggiore) and oligo-mesotrophic (Lake Garda) conditions (Salmaso et al., 2007; Mosello et al., 2010). Because of their depth, the lakes are olo-oligomictic; long periods of incomplete spring mixing are interrupted by complete overturns promoted by harsh and windy winters (Ambrosetti and Barbanti, 1999). We tested whether between-year changes in Daphnia population phenology and maximum density in spring were coherent between lakes, and whether they might be explained by a common response to the same meteoclimatic forcing, expressed by winter teleconnection patterns. We hypothesized that changes in winter water temperature driven by a common climatic forcing acting at a regional scale affected betweenyear changes in time at start of Daphnia population growth. We also hypothesized that timing at start of Daphnia population growth was related to timing at Daphnia maximum spring density peak. We further hypothesized that the level of Daphnia spring population density peak attained each year was not directly consequent to climate change, being mediated by food availability. We based our hypothesis of a food-mediated impact on Daphnia maximum population density on the knowledge that a peak in fecundity precedes Daphnia spring density peak in Lake Maggiore; that, indeed, Daphnia fecundity (as defined in Manca et al., 2008a) can be regarded as an indirect estimate of food availability, the latter being difficult to estimate from field data (Manca et al., 1994). In Lake Maggiore, over the longterm (1978-present), Daphnia year maximum clutch size has been detected after spring phytoplankton Standing Stock Biomass (SSB) peak (Manca et al., 2000a), as also suggested by the so-called PEG (Plankton Ecology Group) model of plankton seasonal succession (Sommer et al., 1986; Manca et al., 2008b). This hypothesis is further based on recent observations carried out in Lake Garda and in the other deep lakes south of the Alps which demonstrated a strong impact of the winter EA and EMP on the winter air and spring lake temperatures, spring deep mixing dynamics, replenishment of phosphorus in the epilimnetic layers, and development of phytoplankton during spring and summer (Salmaso, 2012; Salmaso et al., 2013).

\section{METHODS}

\section{Sampling, field measurements and laboratory analyses}

The data were collected in the framework of the Long Term Ecological Research (LTER-Italy) carried out in Lakes Maggiore and Garda between 1998 and 2008 (Salmaso et al., 2007). This time window was chosen taking into account the availability of data, and because it is long enough to detect common temporal patterns in response to climatic forcing, while allowing for ruling out confounding factors, such as changes in algal nutrient concentrations and in predation pressure by fish and invertebrates (Manca and Ruggiu, 1998; Manca and DeMott, 2009; Manca, 2011).

Air temperature was recorded in the meteorological stations of Pallanza (CNR-ISE), along the shores of Lake Maggiore, and of Arco, around $5 \mathrm{~km}$ away from the northern border of Lake Garda. Water temperatures were measured with multiparameter probes (Garda) or with mercury-filled Celsius thermometers (Maggiore) every month and every two weeks in Garda and Maggiore, respectively. In this work, we will use the temperatures measured in the $0-50 \mathrm{~m}$ water layer, which coincides with the layer where zooplankton was traditionally sampled for long-term monitoring of deep lakes (de Bernardi et al., 1990; Salmaso and NaselliFlores, 1999). The choice of this layer was also justified because our interest was directed towards biological response to common climate drivers, rather than to direct impact of climate on water temperature, traditionally investigated by using lake surface water temperatures (LSWTs; Livingstone and Dokulil, 2001; Dokulil et al., 2010). Soluble reactive phosphorus (SRP) at spring overturn was determined following standard methods (Mosello et al., 1997; Salmaso and Cerasino, 2012), on samples collected in the epilimnetic layers $(0-20 \mathrm{~m})$.

The impact of atmospheric modes of circulation on the limnological variables and the populations of Daphnia in the two lakes were tested using 3 indices relevant or potentially relevant for the southern subalpine region 
(Salmaso, 2012). The winter (December-February) North Atlantic Oscillation $\left(\mathrm{NAO}_{\mathrm{DJF}}\right)$ and the winter East Atlantic pattern $\left(\mathrm{EA}_{\mathrm{DJF}}\right)$ were computed by the NOAA-CPC (www.cpc.ncep.noaa.gov). The winter Eastern Mediterranen Pattern $\left(\mathrm{EMP}_{\mathrm{DJF}}\right)$ was computed following Hatzaki et al. (2007). While winter NAO has been successfully applied to lakes in North America and Central Europe, the other two teleconnection indices have been increasingly used to explain temporally coherent changes in air and water temperature in lakes from the southern slide of the subalpine region (Salmaso and Cerasino, 2012). The EA pattern is defined by a center located near $55^{\circ} \mathrm{N}, 20^{\circ}-35^{\circ}$ $\mathrm{W}$ and an opposite one over North Africa and the Mediterranean Sea $\left(25^{\circ}-35^{\circ} \mathrm{N}, 0^{\circ}-10^{\circ} \mathrm{W}\right)$. Compared with the nodal lines of the NAO, the two anomaly centres of the EA pattern are displaced southeast ward. For this reason the EA pattern is often interpreted as a southward shifted NAO pattern. In its negative state, the $\mathrm{EA}_{\mathrm{DJF}}$ pattern is characterised by intense high pressure over the West Atlantic, causing a north-easterly airflow, which brings cold air from continental Europe over the full Mediterranean basin. Cold winters over the Mediterranean area are, instead, associated with positive values of the $\mathrm{EMP}_{\mathrm{DJF}}$.

In lakes Maggiore and Garda zooplankton was sampled around every two weeks and every month, respectively. In both lakes, zooplankton was collected by vertical tows from $50 \mathrm{~m}$ to the surface. Details on samplings and population density estimations were reported in Manca and Ruggiu (1998) and Salmaso and Naselli-Flores (1999). The temporal dynamics of Daphnia in relation with the climatic fluctuations and water temperatures were evaluated based on different descriptors. The Daphnia start of population density increase $\left(\mathrm{D}_{\text {start }}\right)$ was assessed taking the Julian day at which Daphnia population density level reached at least 400 ind $\cdot \mathrm{m}^{-3}$ and 500 ind $\cdot \mathrm{m}^{-3}$ in Lake Maggiore and Lake Garda, respectively. The choice of these two threshold density levels was based on analyses of Daphnia pluriannual seasonal dynamics over the time period selected for the two lakes. It was justified by the fact that in some years Daphnia persisted all over the year, therefore making it difficult to define an initial state of density increase above zero. The timing of Daphnia population density peak was also investigated in the two lakes, i.e. the Julian date of Daphnia spring peak (between May and June; $D_{\text {peak } 1} D=$ day). We also analysed temporal coherence of Daphnia spring density peak in the two lakes (defined as the maximum population density peak recorded between May and June; $\mathrm{P}_{\text {peak } 1 ;} \mathrm{P}=$ population density).

\section{Data analysis}

The three teleconnection indices $\left(\mathrm{NAO}_{\mathrm{DJF}}, \mathrm{EA}_{\mathrm{DJF}}\right.$ and $\mathrm{EMP}_{\mathrm{DJF}}$ ) were related to selected limnological variables describing the physical and chemical characteristics of the water column during and after the period of maximum spring overturn (between March and April), and to the variables describing the temporal dynamics of Daphnia. The environmental variables include the mean winter air temperatures computed in the period from December to February $\left(\right.$ Tair $\left._{\mathrm{DJF}}\right)$, the spring water temperatures between 0 and $50 \mathrm{~m}\left(\mathrm{~T}_{0-50 \mathrm{~S}}\right)$, and the maximum concentrations of epilimnetic (0-20 m) SRP at spring overturn ( $\left.\mathrm{SRP}_{\text {epis }}\right)$. The relationships between different explanatory (EV) and response variables (RV) were evaluated using Generalised Least Squares models (GLS). In every model, GLS was applied including lake as a categorical variable; single limnological or biological variables as continuous explanatory variables (EV); and a lake-EV interaction term:

$$
R V_{i j}=\alpha_{j}+\beta_{j} \times E V_{i j}+\varepsilon_{i j}
$$

where $i$ and $j$ are indices for the observations of the two lakes, respectively; and $\varepsilon$ is the residual errors (Zuur et al., 2009; Tab. 1). Selection of models was evaluated based on the small sample Akaike Information Criterion (AICc), which includes a correction for finite sample sizes (Burnham and Anderson, 2004). AIC is known for inadequate penalization of complex models, therefore the selection process was confirmed also computing BIC (Bayesian Information Criterion). BIC is more conservative, i.e. the number of parameters have a higher penalty than in the AIC (Zuur et al., 2009; Hastie et al., 2009). Different intercepts and slopes were included only if significant (at least $\mathrm{P}<0.05$ ). Independence of residuals was confirmed in all the tested models by computing the Breusch-Godfrey test ( $\mathrm{P}$ always $>0.05$ ). Statistical analyses and statistical graphs were calculated in R 3.0.0 (R Core Team, 2013).

Taking into account the strict correlation between EA and EMP (see below), the graphs will report only the relationships between EA and the environmental variables. Complete statistical results (including EMP) have been reported in Tab. 1.

\section{RESULTS}

The winter $\mathrm{NAO}\left(\mathrm{NAO}_{\mathrm{DJF}}\right)$ did not have any impact $(\mathrm{P}>0.1)$ on the winter air temperatures $\left(\mathrm{Tair}_{\mathrm{DJF}}\right)$ measured in lakes Maggiore and Garda. Similarly, the relationships between the minimum winter water temperatures $\left(\mathrm{T}_{0-50 \mathrm{~S}}\right)$ and $\mathrm{NAO}_{\mathrm{DJF}}$ was non significant in both lakes. In the same way, $\mathrm{NAO}_{\mathrm{DJF}}$ did not show any significant relationship with the other response variables considered in this work $(\mathrm{P}>0.10)$. Air temperatures measured in Lake Garda were lower than those measured in Lake Maggiore. The meteorological station in Lake Garda is located in the northern part of the lake, where air temperature is by far lower than in the southern part of the lake basin (Neteler et al., 2011). The strict correlation between the winter $\mathrm{EA}$ pattern $\left(\mathrm{EA}_{\mathrm{DJF}}\right)$ and the winter Eastern Mediterranean Pattern $\left(\mathrm{EMP}_{\mathrm{DJF}}\right)$ (Salmaso, 
2012) was confirmed also in this dataset (1998-2008; $\mathrm{r}=-0.92 ; \mathrm{P}<0.001) . \mathrm{EA}_{\mathrm{DJF}}$ and $\mathrm{EMP}_{\mathrm{DJF}}$ strictly controlled $(\mathrm{P}<0.05)$ the interannual temporal development of the winter air temperatures $\left(\right.$ Tair $\left._{\mathrm{DJF}}\right)$ (Tab. 1; Fig. 1a). Based on the AICc values, the final models did not include different slopes and intercepts. Spring water temperatures showed a strong dependence on $\mathrm{EA}_{\mathrm{DIF}}$ and $\mathrm{EMP}_{\mathrm{DIF}}$ (Tab. 1; Fig. 1b). Contrary to air temperature, the spring water temperatures showed significant different intercepts, indicating that mean winter temperatures in Lake Maggiore were $1.6^{\circ} \mathrm{C}$ lower than those measured in the same years in Lake Garda.

The time at start of Daphnia populations $\left(\mathrm{D}_{\text {start }}\right)$ showed a significant $(\mathrm{P}<0.05)$ negative coupling with $\mathrm{EA}_{\text {DJF }}$ (Fig. 2a). The computations did not include an outlier highlighted in the figure. $\mathrm{D}_{\text {start }}$ did not differ between the two lakes for slope of the curve, suggesting that it might be driven by a common meteoclimatic forcing. The same considerations could apply to the relationships between $\mathrm{D}_{\text {start }}$ and $\mathrm{EMP}_{\mathrm{DJF}}$ (Tab. 1). Nevertheless, in this case, the value of the slope was not significant $(\mathrm{P}=0.10)$. The relationships between the two teleconnection indices and $\mathrm{D}_{\text {start }}$ were mediated by water temperature at spring overturn (Fig. 2b). The time at start of Daphnia population growth showed a strong dependence $(\mathrm{P}<0.01)$ from the mean water temperatures in winter, i.e. in a month preceding Daphnia start of seasonal increase. The range of winter temperatures differed for the two lakes, Lake Maggiore spanning between 6.2 and $7.5^{\circ} \mathrm{C}$ and Lake Garda between 7.5 and $9.4^{\circ} \mathrm{C}$. Within the range of variation in $\mathrm{T}_{0-50 \mathrm{~S}}$, Daphnia modulated time at start of population growth by ca. 50-60 days in both lakes, although being the two shifted for range of variation, in Lake Maggiore

Tab. 1. Effects of the winter East Atlantic pattern $\left(\mathrm{EA}_{\mathrm{DJF}}\right)$ and the winter Eastern Mediterranean Pattern $\left(\mathrm{EMP}_{\mathrm{DJF}}\right)$ on Tair ${ }_{\mathrm{DJF}}(\mathrm{winter}$ air temperature), $\mathrm{T}_{0-50 \mathrm{~S}}$ (spring water temperatures between 0 and $\left.50 \mathrm{~m}\right), \mathrm{D}_{\text {start }}$ (Daphnia start of population density increase), $\mathrm{P}_{\text {peak } 1}$ (spring density peak of Daphnia). A selection of other relationships (including $\mathrm{SRP}_{\text {epis }}$, maximum concentrations of epilimnetic $\mathrm{SRP}$ at spring overturn) is reported at the bottom of the table. The columns report the parameters of the models selected by the small sample Akaike Information Criterion (AICc) and Bayesian Information Criterion (BIC). Underlined figures indicate the better models (the lower the better).

\begin{tabular}{|c|c|c|c|c|c|c|c|c|}
\hline EV (X), RV (Y) & Intercept(s) & $\begin{array}{l}\text { Slope (SE); } \\
\text { t-values P }\end{array}$ & $\begin{array}{l}\text { RSE; } \\
\text { df }\end{array}$ & $\begin{array}{l}\mathrm{AICC}^{\circ} \\
\mathrm{BIC}^{\circ}\end{array}$ & $\begin{array}{l}\mathrm{AICC}^{\#} \\
\mathrm{BIC}^{\#}\end{array}$ & $\begin{array}{l}\mathrm{AICC}^{\S} \\
\mathrm{BIC}^{\S}\end{array}$ & $\begin{array}{l}\mathrm{AICc}^{\wedge} \\
\mathrm{BIC}^{\wedge}\end{array}$ & Figure \\
\hline $\mathrm{EA}_{\mathrm{DJF}}, \mathrm{Tair}_{\mathrm{DJF}}$ & 3.95 & $\begin{array}{c}0.796(0.19) \\
4.25^{* * *}\end{array}$ & $0.777 ; 20$ & $\underline{56.6}$ & $\begin{array}{l}59 \\
61\end{array}$ & $\begin{array}{c}62 \\
63.7\end{array}$ & $\begin{array}{l}59.2 \\
61.3\end{array}$ & Fig. 1a \\
\hline $\mathrm{EA}_{\mathrm{DJF}}, \mathrm{T}_{0-50 \mathrm{~S}}$ & $\begin{array}{l}\text { G, 8.37; } \\
\text { M, 6.79 }\end{array}$ & $\begin{array}{c}0.39(0.06) \\
6.36^{* * *}\end{array}$ & $0.254 ; 19$ & $\begin{array}{l}61.2 \\
63.2\end{array}$ & $\underline{9.2}$ & $\begin{array}{l}11.5 \\
13.2\end{array}$ & $\begin{array}{l}63.6 \\
65.6\end{array}$ & Fig. $1 \mathrm{~b}$ \\
\hline $\mathrm{EA}_{\mathrm{DJF}}, \mathrm{D}_{\text {start }}$ & 120.2 & $\begin{array}{c}-7.39(3.45) \\
-2.14^{*}\end{array}$ & $14.32 ; 19$ & $\underline{176.7}$ & $\begin{array}{l}177.3 \\
179.0\end{array}$ & $\begin{array}{l}180.5 \\
181.7\end{array}$ & $\begin{array}{l}179.2 \\
180.9\end{array}$ & Fig. $2 \mathrm{a}$ \\
\hline $\mathrm{EA}_{\mathrm{DJF}}, \mathrm{P}_{\text {peak } 1}$ & 2559.2 & $\begin{array}{c}-1718(364) \\
-4.72^{* * *}\end{array}$ & $1512 ; 20$ & $\underline{389.8}$ & $\begin{array}{l}392.4 \\
394.4\end{array}$ & $\begin{array}{l}394.8 \\
396.5\end{array}$ & $\begin{array}{l}392 \\
394\end{array}$ & Fig. 3a \\
\hline $\mathrm{EMP}_{\mathrm{DJF}}$, Tair $_{\mathrm{DJF}}$ & $\begin{array}{c}4.2(0.17) \\
24.5^{* * *}\end{array}$ & $\begin{array}{c}-0.77(0.18) \\
-4.20^{* * *}\end{array}$ & $0.782 ; 20$ & $\underline{56.8}$ & $\begin{array}{l}59.3 \\
61.3\end{array}$ & $\begin{array}{c}62.3 \\
64\end{array}$ & $\begin{array}{l}59.3 \\
61.3\end{array}$ & \\
\hline $\mathrm{EMP}_{\mathrm{DJF}}, \mathrm{T}_{0-50 \mathrm{~S}}$ & $\begin{array}{l}\text { G, 8.49; } \\
\text { M, 6.91 }\end{array}$ & $\begin{array}{c}-0.37(0.06) \\
-5.88^{* * *}\end{array}$ & $0.267 ; 19$ & $\begin{array}{l}61.4 \\
63.4\end{array}$ & $\frac{11.5}{13.5}$ & $\begin{array}{l}14.2 \\
15.9\end{array}$ & $\begin{array}{l}63.8 \\
65.8\end{array}$ & \\
\hline $\mathrm{EMP}_{\mathrm{DJF}}, \mathrm{D}_{\text {start }}$ & 118 & $\begin{array}{l}5.99(3.50) \\
\quad 1.71 \mathrm{~ns}\end{array}$ & $14.85 ; 19$ & $\underline{178.2}$ & $\begin{array}{l}178.8 \\
180.5\end{array}$ & $\begin{array}{l}181.3 \\
182.5\end{array}$ & $\begin{array}{l}181.0 \\
182.7\end{array}$ & \\
\hline $\mathrm{EMP}_{\mathrm{DJF}}, \mathrm{P}_{\text {peak } 1}$ & 1985 & $\begin{array}{c}1866(300) \\
6.21^{* * *}\end{array}$ & $1284 ; 20$ & $\underline{382.6}$ & $\begin{array}{l}385 \\
387\end{array}$ & $\begin{array}{l}384.8 \\
386.5\end{array}$ & $\begin{array}{l}381.5^{\$} \\
383.6^{\$}\end{array}$ & \\
\hline $\mathrm{T}_{0-50 \mathrm{~S}}, \mathrm{D}_{\text {start }}$ & 203.1 & $\begin{array}{c}-11.27(3.72) \\
-3.03^{* *}\end{array}$ & $15.56 ; 20$ & $\underline{188.4}$ & $\begin{array}{l}188.8 \\
190.8\end{array}$ & $\begin{array}{l}191.9 \\
193.6\end{array}$ & $\begin{array}{l}189 \\
191\end{array}$ & Fig. $2 b$ \\
\hline$D_{\text {start }}, D_{\text {peak } 1}$ & 49.2 & $\begin{array}{c}0.75(0.19) \\
3.91^{* * *}\end{array}$ & $16.20 ; 20$ & $\underline{190.2}$ & $\begin{array}{l}193.2 \\
195.2\end{array}$ & $\begin{array}{l}196.6 \\
198.3\end{array}$ & $\begin{array}{l}193.2 \\
195.2\end{array}$ & Fig. $2 \mathrm{c}$ \\
\hline $\mathrm{T}_{0-50 \mathrm{~S}}, \mathrm{P}_{\text {peak } 1}$ & $\begin{array}{l}\text { G, 29210; } \\
\text { M, } 23799\end{array}$ & $\begin{array}{c}-3166(887) \\
-3.57^{* *}\end{array}$ & $1736 ; 19$ & $\begin{array}{l}405.3 \\
407.2\end{array}$ & $\underline{397.8}$ & $\begin{array}{l}400.9 \\
402.6\end{array}$ & $\begin{array}{l}398.4 \\
400.4\end{array}$ & \\
\hline $\mathrm{SRP}_{\text {epis }}, \mathrm{P}_{\text {peak } 1}$ & 31.7 & $\begin{array}{c}285.0(68.6) \\
4.15^{* * *}\end{array}$ & $1610 ; 20$ & $\underline{392.6}$ & $\begin{array}{l}392.8 \\
394.8\end{array}$ & $\begin{array}{c}396 \\
397.8\end{array}$ & $\begin{array}{l}392.9 \\
394.9\end{array}$ & Fig. $3 b$ \\
\hline
\end{tabular}

SE, standard error; RSE, residual standard errors; $d f$, degrees of freedom; ${ }^{\circ} \mathrm{RV}_{\mathrm{i}}=\alpha+\beta \times \mathrm{EV}_{\mathrm{i}}+\varepsilon_{\mathrm{i}}, 1$ unique regression line; ${ }^{*} \mathrm{RV}_{\mathrm{ij}}=\alpha_{\mathrm{j}}+\beta \times \mathrm{EV}_{\mathrm{ij}}+\varepsilon_{\mathrm{ij}}, 1$ regression line per lake, with equal slopes; ${ }^{\circledR} \mathrm{RV}_{\mathrm{ij}}=\alpha_{\mathrm{j}}+\beta_{\mathrm{j}} \times \mathrm{EV}_{\mathrm{ij}}+\varepsilon_{\mathrm{ij}}$, 1 regression line for each lake (full model); $\mathrm{RV}_{\mathrm{ij}}=\alpha_{\mathrm{j}}+\beta_{\mathrm{j}} \times \mathrm{EV}_{\mathrm{ij}}+\varepsilon_{\mathrm{ij}}$, 1 regression line for each lake, with 1 unique intercept (see Zuur et al., 2009); ${ }^{\text {n }}$ non significant $(P>0.10) \beta_{\mathrm{j}}$ in the fourth model. G, Garda, M, Maggiore; ${ }^{* * *} P<0.001$; ${ }^{* *} P<0.01 ;{ }^{*} P<$ $0.05 ;$ is, not significant. 
between 100 and 150 days, and in Lake Garda between 70 and 130 Julian days, with difference between the means of 13 days.

The start of Daphnia population growth was in turn highly correlated $(\mathrm{P}<0.01)$ with the timing of Daphnia spring population density peak $\left(\mathrm{D}_{\text {peak }}\right.$; Fig. $2 \mathrm{c}$; Tab. 1). The complete overlapping of data from the two lakes and the common slope and intercept indicate that, once promoted, population density increase resulted into coherent delay in peak timing of Daphnia in the two lakes. Peak timing therefore appears like a simple, linearly delayed consequence of time at start of population growth. Daphnia spring population density peak $\left(\mathrm{P}_{\text {peak } 1}\right)$ showed a negative relationship with $\mathrm{EA}_{\text {DJF }}(\mathrm{P}<0.001$; Fig. 3a) and a positive relationship with $\mathrm{EMP}_{\mathrm{DJF}}(\mathrm{P}<0.001)$ (Tab. 1).
Slopes and intercepts of $\mathrm{P}_{\text {peak } 1}$ were not statistically different in the two lakes. Within the range of population density and of teleconnection indices values relative to the time window we analyzed, Daphnia tended to reach higher maximum density levels at negative EA values, and positive EMP values (Tab. 1) corresponding in both cases to lower water temperatures. In fact, $\mathrm{P}_{\text {peak } 1}$ in both lakes showed a strong $(\mathrm{P}<0.01)$ and negative relationship with spring water temperature, $\mathrm{T}_{0-50 \mathrm{~S}}$ (Tab. 1). Interestingly, $D_{\text {peak } 1}$ values in the two lakes were not correlated $(\mathrm{P}>0.1)$ with the spring water temperatures. $\mathrm{P}_{\text {peak } 1}$ was strongly connected $(\mathrm{P}<0.01)$ with the epilimnetic spring $\mathrm{SRP}$ concentration $\left(\mathrm{SRP}_{\mathrm{epis}}\right)$ (Fig. $\left.3 b\right)$. The regression lines best fitting the data of the two lakes did not differ for slope and intercept (Tab. 1). A ca. twofold increase in
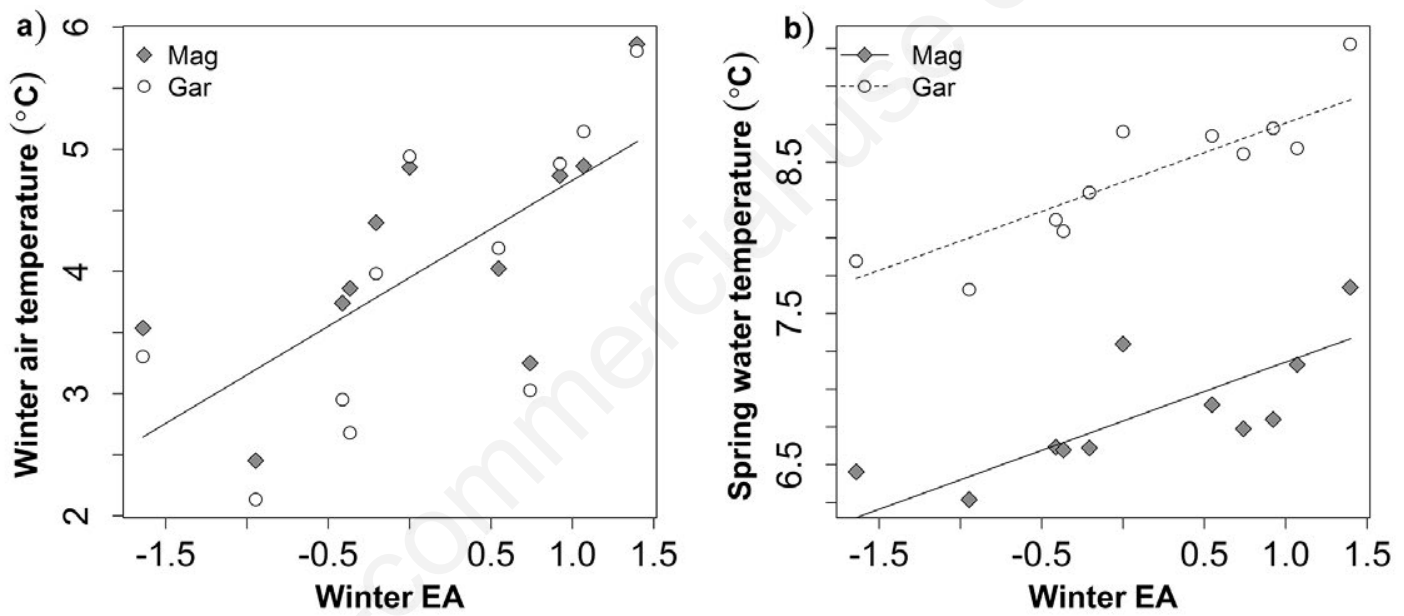

Fig. 1. Effects of the winter values of the East Atlantic pattern $\left(E_{D J F}\right)$ on the (a) winter air ( Tair $\left._{D J F}\right)$ and (b) spring water (0-50 m depth) temperatures $\left(\mathrm{T}_{0-50 \mathrm{~s}}\right)$ in lakes Maggiore (Mag) and Garda (Gar) (1998-2008). Statistical analyses are reported in Tab. 1.
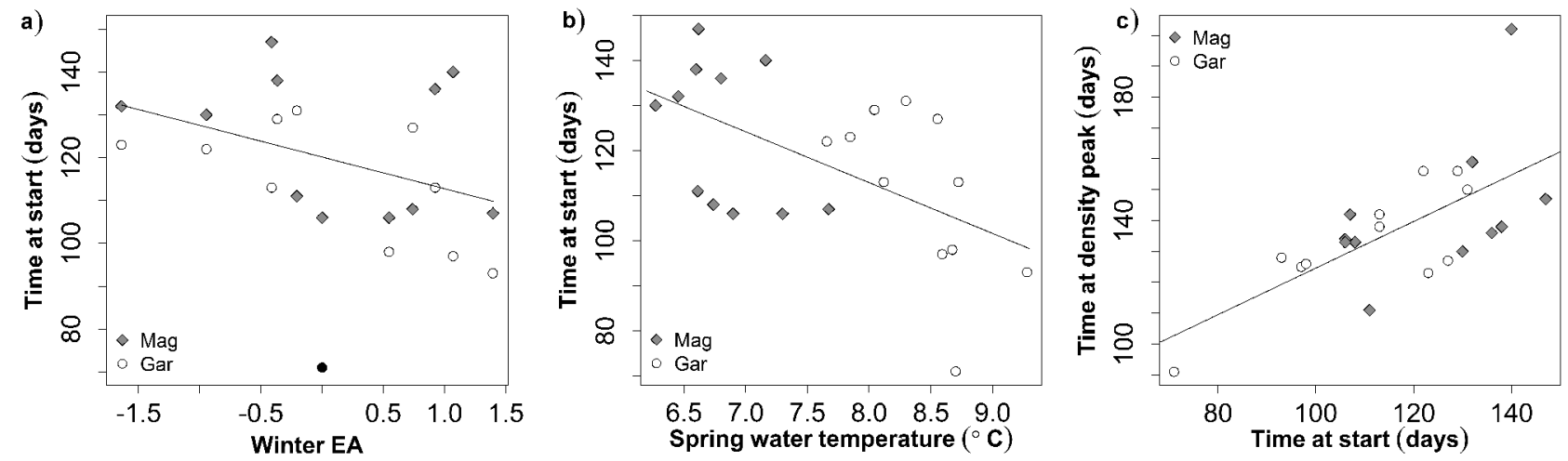

Fig. 2. Effects of (a) the winter East Atlantic pattern $\left(\mathrm{EA}_{\mathrm{DJF}}\right)$, and (b) spring water temperature $\left(\mathrm{T}_{0-50 \mathrm{~S}}\right)$ on time at start of Daphnia population growth $\left(\mathrm{D}_{\text {start }}\right)$. c) Effect of $\mathrm{D}_{\text {start }}$ on time at density peak $\left(\mathrm{D}_{\text {peak } 1}\right)$ of Daphnia populations in lakes Garda and Maggiore, 19982008. Statistical analyses are reported in Tab. 1. 
SRP concentration resulted in doubling of $\mathrm{D}_{\text {peak } 1}$ level, with an increase in spring density peak of Daphnia population of 285 ind. $\mathrm{m}^{-3}$ for $1 \mu \mathrm{g} \mathrm{L}^{-1}$ SRP increase.

Overall, our results suggest a complex effect of winter water temperatures on the seasonal development of Daphnia populations in the two lakes. We summarized these complex interactions in Fig. 4, which will be discussed in the next section.

\section{DISCUSSION}

In most studies investigating interactions between climate change and zooplankton spring development, teleconnection indices developed for North and Central Europe and North America were applied, thus reflecting the origin and initial development of these studies. While being able to predict changes in plankton seasonality also in response to duration of the ice cover and melting timing (George et al., 2004), these indices resulted fully inappropriate when applied to the deep lakes in the southern slide of the subalpine region (Salmaso, 2005, 2012; Salmaso et al., 2013). The lower impact of NAO is likely a consequence of a sheltering effect of the Alps on the climate patterns prevailing in Northern and Central Europe. In this work, by using the two lakes representative of the easternmost and westernmost part of the subalpine region, we were able to prove that the influence of the two teleconnection indices (EA and EMP) on the zooplankton dynamics was extended to the entire subalpine region.

Warming is often regarded as a factor able to worsen the effects of eutrophication, resulting in similar patterns of change, although originating from different mechanisms (Schindler, 2001; Winder and Sommer, 2012). Our data are representative of a time window in which the two lake systems did not show strong changes in the trophic conditions. In the considered period, Lake Maggiore was fully recovered from eutrophication, with well balanced, stable plankton communities. As for Lake Garda, the between-year fluctuations in the availability of nutrients in the same period were far more important compared with the long-term decadal changes (Salmaso, 2012). In addition, as shown in previous works (Salmaso et al., 2013) which analyzed more extended periods and a larger number of lakes, the comparison of the regressions obtained with the de-trended and non de-trended series provide equivalent results. Nevertheless, an effect of other trophyrelated changes in e.g. fish predation pressure on the analyzed relationship cannot be excluded. Studies on climate impact are commonly restricted to analyses of surface water temperatures, which are much more influenced by daily variations and of biological restricted relevance. The focus on surface water temperature was related to the possibility of applying satellites for detecting temperature change at large scale (Schneider et al., 2009). Owing to our interest in Daphnia, we considered winter water temperatures of the water layer where the species was mainly distributed, particularly in spring, i.e. the upper $50 \mathrm{~m}$ depth. The use of temperature data of this water layer could in turn explain the high degree of temporal coherence of the two lakes.

We interpreted temporal coherence of data from the two lakes on Daphnia seasonal growth timing (time at onset and time at maximum Daphnia population density growth) as consequent to the impact of common atmospheric circulation patterns described by EA and EMP. The
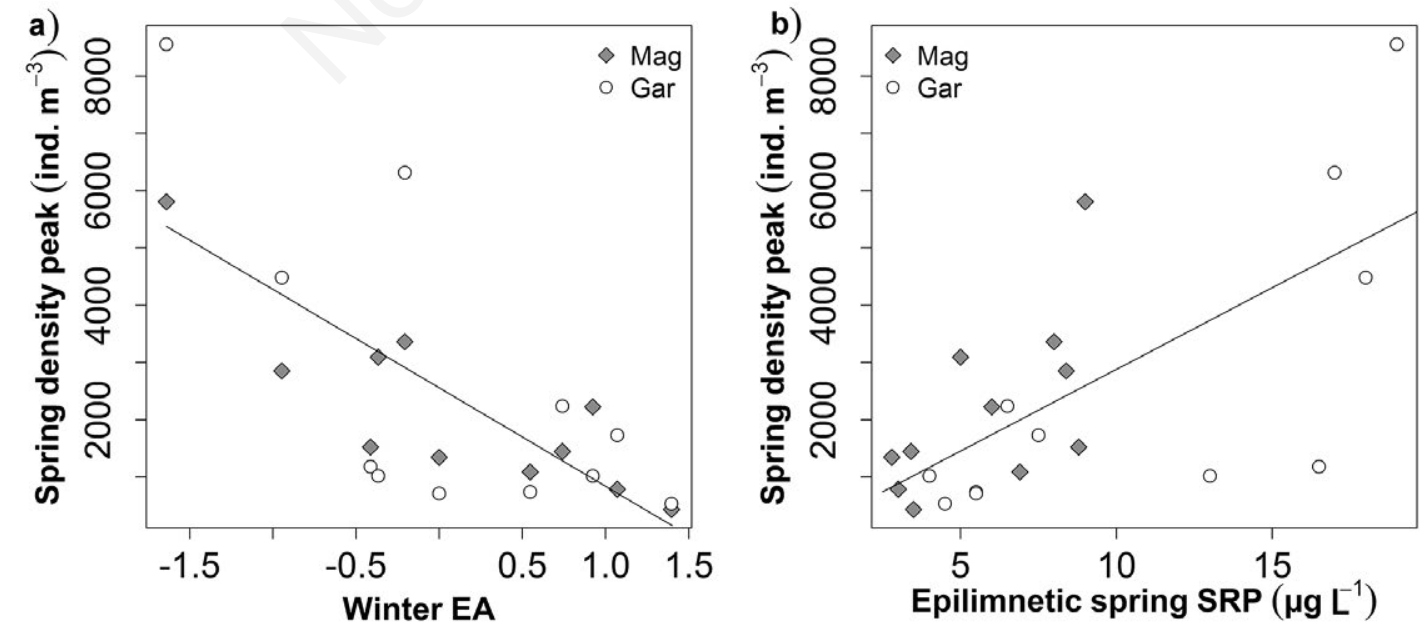

Fig. 3. Effects of the winter values of (a) the East Atlantic pattern $\left(E A_{D J F}\right)$ on Daphnia population spring density peak ( $\left.P_{\text {peak } 1}\right)$ in lakes

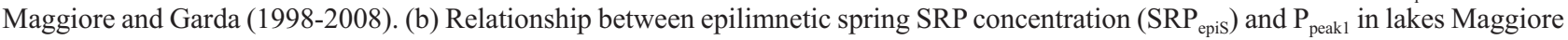
and Garda (1998-2008). Statistical analyses are reported in Tab. 1. 
results are therefore consistent with those obtained in Central and Northern Europe, as well as North America, where other teleconnection indices for the winter period were applied (Irigoien et al., 2000; Straile, 2000, 2002; Piontkovski et al., 2006). Similarly to those studies, time at start was in turn correlated with timing at which the major population density peak was attained (Straile et al., 2003; Schalau et al., 2008). Such a correlation was also found for predatory zooplankters, not least Bythotrephes, in Lake Maggiore (Manca and DeMott, 2009). Timing at density peak can be therefore regarded as a delayed response to the same common cue which promoted initial population growth, i.e. winter temperature. Our results also suggest that time lag between time at start and time at peak in Daphnia population density tends to be relatively constant between the two lakes. The high betweenlake coherence in delta time at $\left(D_{\text {start }}-D_{\text {peak }}\right)$, suggests that warming rate and rate of increase in food conditions are basically the same in the two lakes, therefore suggesting that the two lakes respond to warming coherently and environmental conditions promoting initial development also promote those causing subsequent development of the population; therefore environmental conditions will be relevant for Daphnia to promote initial development, later on being the population somewhat resilient to external perturbations (homeostasis).

In our study, increasing levels of Daphnia abundance were, at a high between-lake temporal coherence, inversely correlated to warming-associated modes of variations of both teleconnection indices applied. Negative relationship of Daphnia peak densities with milder winters (less phosphorus due to less mixing) was predicted from e.g. mesocosm experiments (Berger et al., 2007) and modeling studies (Schalau et al., 2008). Both studies show that algal carrying capacity, experimentally modified by modifying light availability in the mesocosm studies of Berger et al. (2007), and tested in different modeling scenarios by Schalau et al. (2008) would enhance peak densities of Daphnia. Based on the direct, highly between-lake coherent and significant correlation between Daphnia population density peak level and SRP concentration, we hypothesize that the level of peak reached by Daphnia in spring is indirectly related to winter water temperature, being mediated by the degree of winter mixing, which in turn regulates the algal carrying capacity. Our hypothesis is supported by previous works on Lake Maggiore (Manca et al., 2000a, 2000b) demonstrating that the initial phase of increase in phytoplankton biomass is translated within a certain time lag into a peak in Daphnia mean clutch size and fecundity. At a time of the year between Daphnia initial growth and Daphnia density peak, a relatively low number of ovigerous females within the population carry a high number of eggs/clutch, an expression of increase in fecundity of
Daphnia population related to increase in food availability (Manca et al., 2000a). The level attained on each year is dependent from phytoplankton development, which in turn depends on phosphorus concentration (Salmaso et al., 2013). In fact, spring Daphnia clutch size during the mesotrophic phase of Lake Maggiore was found to be double than that measured after the reversal of eutrophication (Manca et al., 2000a). Similarly, as observed in Lake Iseo (Leoni et al., 2014), it was demonstrated how a complete winter mixing event during the oligotrophic phase could promote an increase in Daphnia clutch size to values of the mesotrophic phase, as a result of increased phytoplankton biomass and primary productivity (Manca

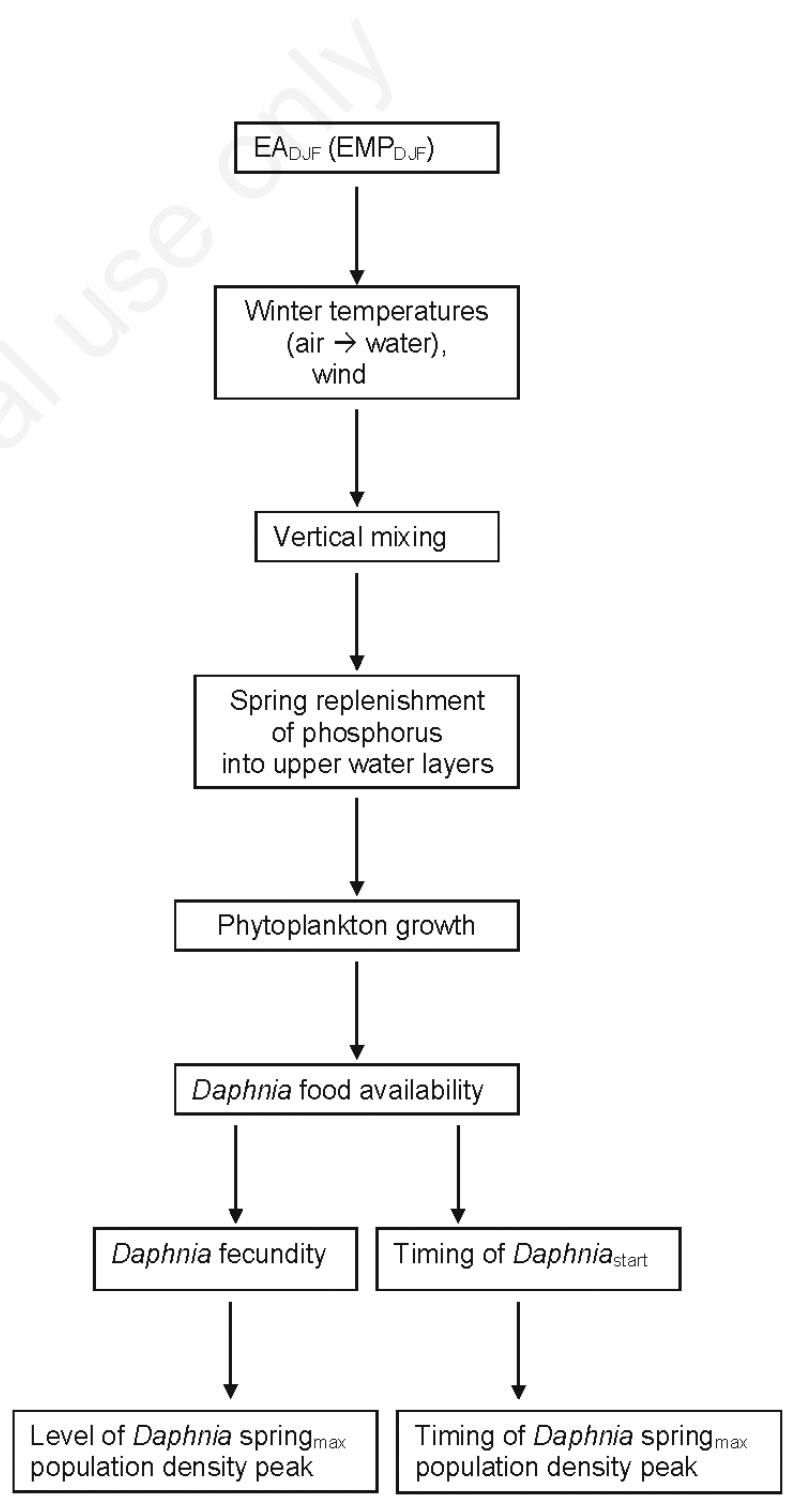

Fig. 4. Schematic interpretation of the interactions between meteoclimatic forcing and Daphnia spring population growth. Control of winter water temperature on Daphnia spring population density growth is indirect, i.e. mediated by food availability. 
et al., 2000b), consequent to an increase in nutrients. The increase in clutch size and fecundity observed with complete winter overturn also resulted in unusually high Daphnia spring population density peak in that year with respect to values measured over the period (Manca et al., 2000b). Similarly, we suggest that temperature indirectly controls the timing of events in the plankton seasonal succession, being mixing depth and phosphorus replenishment for algal growth crucial also in this respect. Laboratory experiments have shown that Daphnia can grow, provided that food is not limiting, at the temperatures our study lakes experience in winter $\left(>6^{\circ} \mathrm{C},>8^{\circ} \mathrm{C}\right)$, therefore suggesting that also start of increase in abundance cannot be constrained by temperature alone. An increase in fecundity is also required for triggering recruitment of newborn into the population, necessary to promote initial population growth.

According to our results, we hypothesize that food availability is the major constrain for Daphnia spring maximum population density level attained in a given year in the two deep subalpine lakes we investigated. The question is therefore on whether, how, and to what extent, is food availability for Daphnia related to meteo-climatic drivers, as suggested by the fact that Daphnia peak density is correlated negatively with winter temperature and positively with spring SRP concentration. Correlation between Daphnia population density and SRP also confirms the Daphnia population density increase during Lake Maggiore eutrophication (Manca et al., 2007). Our hypothesis is that Daphnia peak density level is indirectly related to climatic-forcing, via the same factors which promote increase in spring food sources (Salmaso and Cerasino, 2012; Salmaso et al., 2013; Fig. 3). In our summarizing scheme (Fig. 4), we therefore hypothesize that the increase of algal nutrients in the trophogenic layers triggered by cold winters and specific patterns in the atmospheric modes of circulation, were directly responsible, via an increase in fecundity, of the Daphnia spring density peak. Environmental temperature indirectly affected also timing of Daphnia growth, by enhanced egg production, in turn related to mixing depth and algal carrying capacity. Ongoing research on other main deep subalpine lakes seems to confirm our hypothesis of food mediated Daphnia response to climate forcing.

\section{CONCLUSIONS}

This study represents the first application of two teleconnection indices potentially relevant for the Mediterranean area, namely the East Atlantic pattern (EA) and the Eastern Mediterranean Pattern (EMP), to assess the effects of atmospheric modes of variability on Daphnia population growth in two lakes south of the Alps (Garda and Maggiore). The results of our analyses highlighted the effects of winter water temperatures on the extent of the late winter mixing and, indirectly, on the Daphnia peak densities. More specifically, our data support the hypothesis that the spring maximum densities of Daphnia were related to EA and EMP in winter and, through a linked chain of events, to the degree of late winter mixing, replenishment of algal nutrients into upper water layers, higher phytoplankton growth, enhancing food availability and Daphnia fecundity.

This study confirmed the usefulness of meteo-climatic indices as indicators of climate forcings and predictors of the impact of climate change on the functioning of lake ecosystems. The EA and EMP in particular proved to be suitable climatic indices for the assessment of interannual variability and temporal coherence of several limnological variables in the lakes of the southern subalpine area.

\section{ACKNOWLEDGMENTS}

The present work was funded to MM and MR by the projects on Lake Maggiore zooplankton and water chemistry of the International Commission for the Protection of Italian- Swiss Waters (CIPAIS), research on Lake Maggiore, section limnology. Funds to NS were provided by the EU Central Europe Programme (EULAKES Project, 2CE243P3) and ARPAV. Investigations were made in the framework of the LTER (Long Term Ecological Research) Italian network, site "Southern Alpine lakes", IT08-000-A (http://www.lteritalia.it/).

\section{REFERENCES}

Ambrosetti W, Barbanti L, 1999. Deep water warming in lakes: an indicator of climatic change. J. Limnol. 58:1-9.

Adrian R, O’Reilly CM, Zagarese H, Baines SB, Hessen DO, Keller W, Livingstone DM, Sommaruga R, Straile D, Van Donk, Weyhenmeyer GA, Winder M, 2009. Lakes as sentinels of climate change. Limnol. Oceanogr. 54: 2283-2297.

Berger SA, Diehl S, Stibor H, Trommer G, Ruhenstroth M, Wild A, Striebel M, 2007. Water temperature and mixing depth affect timing and magnitude of events during spring succession of the plankton. Oecologia 150:643-654.

Blenckner T, 2005. A conceptual model of climate related effects on lake ecosystems. Hydrobiologia 533:1-14.

Burnham KP, Anderson DR, 2004. Multimodel inference: understanding AIC and BIC in model selection. Sociol. Methods Res. 33:261-304.

de Bernardi R, Giussani G, Manca M, Ruggiu D, 1990. Trophic status and the pelagic system in Lago Maggiore. Hydrobiologia 191:1-8.

Dokulil MT, Teubner K, Jagsch A, Nickus U, Adrian R, Straile D, Jankowski T, Herzig A, Padisák J, 2010. The impact of climate change on lakes in Central Europe, p. 387-409. In: D.G. George (ed.), The impact of climate change on European lakes. Springer.

George DG, 2010. The impact of climate change on European lakes. Aquatic Ecology Series. 4. Springer: 507 pp.

George DG, Järvinen M, Arvola M, 2004. The influence of the 
North Atlantic Oscillation on the winter characteristics of Windermere (UK) and Pääjärvi (Finland). Boreal Environ. Res. 9:389-399.

George DG, Taylor AH, 1995. UK lake plankton and the Gulf Stream. Nature 378:39.

Hastie T, Tibshirani R, Friedman J, 2009. The elements of statistical learning. Data mining, inference, and prediction. Springer: $745 \mathrm{pp}$.

Hatzaki M, Flocas HA, Asimakopoulosa DN, Maheras P, 2007. The eastern Mediterranean teleconnection pattern: identification and definition. Int. J. Climat. 27:727-737.

Hurrell JW, Kushnir Y, Ottersen G, Visbeck M, 2003. The North Atlantic Oscillation. climatic significance and environmental impact. American Geophysical Union: 279 pp.

Irigoien X, Harris RP, Head RN, Harbour D, 2000. North Atlantic Oscillation and spring bloom phytoplankton composition in the English Channel J. Plankton Res. 22:2367-2371.

Leoni B, Garibaldi L, Gulati RD, 2014. How does interannual trophic variability caused by vertical water mixing affect reproduction and population density of the Daphnia longispina group in Lake Iseo, a deep stratified lake in Italy? Inland Waters 4:193-203.

Livingstone DM, Dokulil MT, 2001. Eighty years of spatially coherent Austrian lake surface temperatures and their relationship to regional air temperatures and to the North Atlantic Oscillation. Limnol. Oceanogr. 46:1220-1227.

Kromp-Kolb H, 2001. [Was wir über den globalen Klimawandel wissen. Wissenschaft und Umwelt].[Article in German]. Available from: http://www.accc.gv.at/publ/UmwFor_KrompKolb.pdf

Manca M, 2011. Invasion and re-emergences: an analysis of the success of Bythotrephes in Lago Maggiore (Italy). J. Limnol. 70:76-82.

Manca M, Cavicchioni N, Morabito G, 2000b. First observations on the effect of complete overturn of Lake Maggiore on plankton and primary production. Int. Rev. Ges. Hydrobiol. 85:209-222.

Manca M, DeMott WR, 2009. Response of the invertebrate predator Bythotrephes to a climate-linked increase in the duration of a refuge from fish predation. Limnol. Oceanogr. 54:506-512.

Manca M, Ramoni C, Comoli P, 2000a. The decline of Daphnia hyalina galeata in Lago Maggiore: a comparison of the population dynamics before and after oligotrophication. Aquat. Sci. 62:142-153.

Manca M, Ruggiu D, 1998. Consequences of pelagic food web changes during a long-term lake oligotrophication process. Limnol. Oceanogr. 43:1368-1373.

Manca M, Spagnuolo T, Comoli P, 1994. Variations in carbon and nitrogen content with body length of Daphnia hyalinagaleata s.l. from laboratory and field observations. J. Plankton Res. 16:1303-1314.

Manca M, Torretta B, Comoli P, Amsinck SL, Jeppesen E, 2007. Major changes in trophic dynamics in large, deep subalpine Lake Maggiore from the 1940s to 2002: A high resolution comparative palaeo-neolimnological study. Freshwater Biol. 52:2256-2269.

Manca M, Vijverberg J, Polishchuk LV, Voronov DA, 2008a. Daphnia body size and population dynamics under predation by invertebrate and fish predators in Lago Maggiore: an ap- proach based on contribution analysis J. Limnol. 67:15-21.

Manca M, Visconti A, de Bernardi R, 2008b. [Lo zooplancton del Lago Maggiore nel quinquennio 2003-2007: tendenze evolutive ed eccezioni alla luce dei cambiamenti globali].[Article in Italian]. Biologia Ambientale 22:64-72.

Menzel A, Sparksw TH, Estrella N, Kochz E, Aasa A, Ahas R, Alm-Kübler $\mathrm{K}$, Bissolli $\mathrm{P}$, Braslavská $\mathrm{O}$, Briede $\mathrm{A}$, Chmielewski FM, Crepinsek Z, Curnel Y, Dahl Á, Defila C, Donnelly A, Filella Y, Jatczak K, Måge F, Mestre A, Nordli Ø, Peñuelas J, Pirinen P, Remišová V, Scheifinger H, Striz M, Susnik A, Van Vliet AJH, Wielgolaski F-E, Zach S, Zust A, 2006. European phenological response to climate change matches the warming pattern. Glob. Change Biol. 12:1969-1976.

Mosello R, Ambrosetti W, Arisci S, Bettinetti R, Buzzi F, Calderoni A, Carrara E, de Bernardi R, Galassi S, Garibaldi L, Leoni B, Manca M, Marchetto A, Morabito G, Oggioni A, Pagnotta R, Ricci D, Rogora M, Salmaso N, Simona M, Tartari G, Veronesi M, Volta P, 2010. [Evoluzione recente della qualità delle acque dei laghi profondi sudalpini (Maggiore, Lugano, Como, Iseo e Garda) in risposta alle pressioni antropiche e alle variazioni climatiche ].[Article in Italian]. Biologia Ambientale 24:167-177.

Mosello R, Calderoni A, de Bernardi R, 1997. [Le indagini sulla evoluzione dei laghi profondi sudalpini svolte dal C.N.R. Istituto Italiano di Idrobiologia].[Article in Italian]. Documenta Ist. Ital. Idrobiol. 61:19-32.

Moss B, Hering D, Green AJ, Aidoud A, Becares E, Beklioglu M, Bennion H, Boix D, Brucet S, Carvalho L, Clement B, Davidson T, Declerk S, Dobson M, van Donk E, Dudley B, Feuchtmayr H, Friberg N, Grenouillet G, Hillebrand H, Hobaek A, Irvine K, Jeppesen E, Johnson R, Jones I, Kernan M, Lauridsen TL, Manca M, Meerhoff M, Olafsson J, Ormerod S, Papastergiadou E, Penning WE, Ptacnik R, Quintana X, Sandin L, Seferlis M, Simpson G, Triga C, Verdonshot P, Verschoor AM, Weyhenmeyer GA, 2009. Climate change and the future of freshwater biodiversity in Europe: a primer for policy-makers. Freshwater Rev. 2:103-130.

Neteler M, Roiz D, Rocchini D, Castellani C, Rizzoli A, 2011. Terra and Aqua satellites track tiger mosquito invasion: modelling the potential distribution of Aedes albopictus in north-eastern Italy. Int. J. Health Geogr. 10:49.

Piontkovski SA, O’Brien TD, F. Umani S, Krupa EG, Stuge ST, Balymbetov KS, Grishaeva OV, Kasymov AG, 2006. Zooplankton and the North Atlantic Oscillation: a basin-scale analysis J. Plankton Res. 28:1039-1046.

R Core Team, 2013. R: a language and environment for statistical computing. R Foundation for Statistical Computing, Vienna, Austria. URL http://www.R-project.org/.

Reynolds CS, 1987. Organization of communities past and present. In: Gee JHR, Giller PS, editors:297-325. Blackwell, Oxford.

Richardson AJ, 2008. In hot water: zooplankton and climate change. ICES J. Mar. Sci. 65:279-295.

Salmaso N, 2005. Effects of climatic fluctuations and vertical mixing on the interannual trophic variability of Lake Garda, Italy. Limnol. Oceanogr. 50:553-565.

Salmaso N, 2012. Influence of atmospheric modes of variability on the limnological characteristics of a deep lake south of the Alps. Clim. Res. 51:125-133. 
Salmaso N, Buzzi F, Cerasino L, Garibaldi L, Leoni B, Morabito G, Rogora M, Simona M, 2013. Influence of atmospheric modes of variability on the limnological characteristics of large lakes south of the Alps: a new emerging paradigm. Hydrobiologia 731:31-48.

Salmaso N, Cerasino L, 2012. Long-term trends and fine yearto-year tuning of phytoplankton in large lakes are ruled by eutrophication and atmospheric modes of variability. Hydrobiologia 698:17-28.

Salmaso N, Morabito G, Garibaldi L, Mosello R, 2007. Trophic development of the deep lakes south of the Alps: a comparative analysis. Fund. Appl. Limnol. 170:177-196.

Salmaso N, Naselli Flores L, 1999. Studies on the zooplankton of the deep subalpine Lake Garda. J. Limnol. 58:56-66.

Schalau K, Rinke K, Straile D, Peeters F, 2008. Temperature is the key factor explaining interannual variability of Daphnia development in spring: a modelling study. Oecologia 157:531-43.

Schindler DW, 2001. The cumulative effects of climate warming and other human stresses on Canadian freshwaters in the new millennium. Can. J. Fish. Aquat. Sci. 58:18-29.

Schneider P, Hook SJ, Radocinski RG, Corlett GK, Hulley GC, Schladow SG, Steissberg TE, 2009. Satellite observations indicate rapid warming trend for lakes in California and Nevada. Geophys Res. Lett. 36:L22402.

Shurin JB, Winder M, Adrian R, Keller W, Matthews B, Paterson AM, Paterson MJ, Pinel-Alloul N, Rusak JA, Yan N, 2010. Environmental stability and lake zooplankton diversity- contrasting effects of chemical and thermal variability. Ecol. Lett. 13:453-463.

Sommer U, Gliwicz ZM, Lampert W, Duncan A, 1986. The PEG model of a seasonal succession of planktonic events in fresh waters. Arch. Hydrobiol. 106:433-71.
Straile D, 2000. Meteorological forcing of plankton dynamics in a large and deep continental European lake. Oecologia 122:44-50.

Straile D, 2002. North Atlantic Oscillation synchronizes foodweb interactions in central European lakes. P. Roy. Soc. Lond. B. Bio. 269:391-395.

Straile D, Livingstone DM, Weyhenmeyer GA, George DG, 2003. The response of freshwater ecosystems to climate variability associated with the North Atlantic Oscillation, $p$. 263-279. In: J.W. Hurrell, G. Ottersen and M. Visbeck (eds.), The North Atlantic Oscillation, climatic significance and environmental Impact. American Geophysical Union.

Taylor AH, Colebrook JM, Stephens JA, Baker NG, 1992. Latitudinal displacements of the Gulf Stream and the abundance of plankton in the north-east Atlantic. J. Mar. Biol. Ass. U.K. 72:919-921

Vadadi-Fülöp C, Hufnagel L, 2014. Climate change and plankton phenology in freshwater: current trends and gaps to be filled. J. Limnol. 73:1-16.

Walther GR, Post E, Convey P, Menzel A, Parmesank C, Beebee TJC, Fromentin JM, Hoegh-Guldberg O, Bairlein F, 2002. Ecological responses to recent climate change. Nature 416:389-395.

Visser ME, Both C, 2005. Shifts in phenology due to global climate change: the need for a yardstick. P. Roy. Soc. Lond. B Bio. 272:2561-2569.

Winder M, Schindler DE, 2004. Climatic effects on the phenology of lake processes. Glob. Change Biol. 10:1844-1856.

Winder M, Sommer U, 2012. Phytoplankton response to a changing climate. Hydrobiologia 698:5-16.

Zuur A, Ieno EN, Walker NJ, Saveliev AA, Smith GM, 2009. Mixed effects models and extensions in ecology with R. Springer: 574 pp. 